\title{
PROTECTION OF ALIEN RIGHTS UNDER THE FOURTEENTH AMENDMENT
}

In Gonzales $v$. Shea ${ }^{1}$ the United States District Court for the District of Colorado held that requiring United States citizenship as a condition of eligibility for receiving benefits under Colorado's Old Age Pension law did not violate the equal protection clause of the fourteenth amendment. ${ }^{2}$ Plaintiffs, resident aliens of the United States and residents of Colorado, would have been eligible to receive benefits under the program had they met the citizenship requirement. They filed a class action ${ }^{3}$ contending that the citizenship requirement constituted an invidious classification and sought declaratory relief ${ }^{4}$ invalidating the requirement. ${ }^{5}$ While recognizing that aliens are protected by the fourteenth amendment, the court held that the state had a substantial interest in upholding the classification and distinguished two other district court decisions ${ }^{6}$ as not involving Colorado's unique pension program. Concluding that a holding of invalidity might destroy the entire pension program, the court granted defendant's motion for summary judgment. ${ }^{7}$

The holding in Gonzales represents a significant departure from the ever increasing judicial solicitude for protection of aliens under the fourteenth amendment. When presented with comparable factual situations and similar attacks upon the constitutionality of statutory restrictions based on alienage, other courts have invalidated such limitations. ${ }^{8}$ Resolution of this conflict in the decisions is extremely

1. 318 F. Supp. 572 (D. Colo. 1970).

2. Colorado's old age pension program was initiated in the form of a state constitutional amendment and provides for the creation and maintenance of a special pension fund while establishing basic qualifications for receipt of payments from that fund. CoLo. Const. art. 24, $\S 1-9 ;$ Colo. Rev. Stat. ANN. $\S \S 101-1-4(1)(a)(f), 101-1-5(1)(a)(c)(1963)$.

3. The suit was filed pursuant to FED. R. Civ. P. 23(a) and (b)(2).

4. Relief was sought pursuant to 28 U.S.C. § 2202 (1964).

5. Plaintiffs also contended that the citizenship requirement denied them due process of law, the right to travel freely interstate, and was contrary to 42 U.S.C. $§ 1981$ (1964), which provides for equal rights under the law for all persons within the jurisdiction of the United States. The court considered the equal protection question to present the sole issue of merit. $318 \mathrm{~F}$. Supp. at 577 .

6. Leger v. Sailer, 321 F. Supp. 250 (E.D. Pa. 1970), prob.juris. noted, 400 U.S. 956 (1970); Richardson v. Graham, 313 F. Supp. 34 (D. Ariz. 1970), prob. juris. noted, 400 U.S. 956 (1970).

7. 318 F. Supp. at 579.

8. Leger v. Sailer, 321 F. Supp. 250 (E.D. Pa. 1970); Hosier v. Evans, 314 F. Supp. 316 (D.V.I. 1970); Richardson v. Graham, 313 F. Supp. 34 (D. Ariz. 1970); Purch \& Fitzpatrick v. State, 71 Cal. 2d 566, 456 P.2d 645, 79 Cal. Rptr. 77 (1969). 
[Vol. 1971:583

significant because state restrictions on alien employment opportunities, ${ }^{9}$ the right to hold land, ${ }^{10}$ and eligibility for state aid ${ }^{11}$ continue to be widespread. Furthermore, consideration of the factors involved in resolving the alien's status under the fourteenth amendment suggests an extension of the equal protection doctrine that would also have implications in reference to classifications based on other factors, such as age and sex.

The standard measure of review under the equal protection clause only requires that the use of a state statutory classification be rationally related to the furtherance of a legitimate state interest. ${ }^{12}$ Constitutional attacks on classifications, the validity of which are measured by this test, are almost uniformly unsuccessful since there need be only some relationship between the classification and a conceivably legitimate state interest. ${ }^{13}$ Also, because only a reasonable relationship is demanded, states have great latitude in determining how inclusive statutory classifications will be. ${ }^{14}$ However, in reviewing certain classifications, the Supreme Court has departed from the traditional permissive standard of review and demanded more compelling justification. ${ }^{15}$

9. State legislation routinely restricts alien participation in various occupations. See, e.g., KY. REv. Stat. ANN. $\$ 243.100(3)$ (1969) (forbidding aliens to sell or transport alcoholic beverages); NEv. REv. STAT. $\S 464.101$ (1967) (prohibiting ownership or operation of gambling devices by aliens); N.M. STAT. ANN. § 46-5-14(a)(2)(b) (1966) (denying aliens employment as dispensers and retailers of alcoholic beverages); S.D. CoMp. LAws ANN. $§ 34-20-9$ (1967) (denying aliens a license to sell poison).

Twenty-two states have conditions for employment on public work projects which deny or grossly restrict employment of aliens in this area. Comment, Equal Protection and Supremacy Clause Limitations on State Legislation Restricting Aliens, 1970 UTAH L. Rev. 136 n.25; see Note, Constitutionality of Restrictions on Aliens' Right to Work, 57 CoLum. L. REv. 1012 (1957). See generally Konvity, The Alien and the Asiatic in American Law (1946); 5 Vernier, AMierican Family Laws \$294 (1938); Chamberlain, Aliens and the Right to Work, 18 A.B.A.J. 379 (1932); Note, Constitutionality of Legislative Discrimination Against the Alien in His Right to Work, 83 U. PA. L. REv. 74 n.9 (1934).

10. For a listing of those limitations, see Sullivan, Alien Land Laws: $A$ Re-Evaluation, 36 TEMP. L.Q. 15, 17-26 (1962).

11. See Note, State Discrimination Against Mexican Aliens, 38 Gzo. WASH. L. Rev. 1091 (1970).

12. Tussman \& tenBroek, The Equal Protection of the Laws, 37 Calif. L. Rev. 341,346 (1949). Developments in the Law-Equal Protection, 82 HARv. L. REv. 1065, 1082 (1969) [hereinafter cited as Developments]. See, e.g., F.S. Royster Guano Co. v. Virginia, 253 U.S. 412 (1920).

13. See McGowan v. Maryland, 366 U.S. 420, 426 (1961); Developments 1083.

14. See Tussman \& tenBroek, supra note 12, at 348; Developments 1085.

15. E.g., Loving v. Virginia, 388 U.S. 1 (1967); Harper v. Virginia Bd. of Elections, 383 U.S. 663 (1966); McLaughlin v. Florida, 379 U.S. 184 (1964); Reynolds v. Sims, 377 U.S. 533 (1964). See Developments 1088. 
Generally speaking, a classification that either affects the exercise of a constitutional right or is based on suspect criteria denies equal protection unless justified by a compelling state interest. ${ }^{16}$ The rationale behind this stepped-up review of classifications affecting constitutional rights is that those rights are of such importance that a state's decision to differentiate among classes of individuals in respect to them must possess more than mere possible rationality. ${ }^{17}$ Following this reasoning, several Supreme Court decisions have been interpreted as establishing that any classification which adversely affects basic civil or personal interests requires a compelling justification. ${ }^{18}$ However, in Dandridge v. Williams ${ }^{19}$ the Court upheld a regulation placing an absolute limit on the amount of welfare a family could receive regardless of its size or actual need. Even though the most basic needs of impoverished human beings were involved, the reasonable basis standard was applied because the Court found that no interest or freedom protected by the Bill of Rights was affected.

On the other hand, judicial identification of classifying factors which are considered suspect and therefore lead to active review is limited, and expliciation of the policy considerations involved in so designating a factor is even more limited..Although several bases of

16. The appropriate occasion for and limits of a stepped-up standard of review have never been definitely articulated. The validity and substance of an actual bipartite pattern of review rested solely upon occasional judicial references to the use of a more intensive standard of review until the Supreme Court openly indicated its utilization of a dual standard in Shapiro v. Thompson, 394 U.S. 618 (1969). Legal commentators conceptualized general notions concerning when active scrutiny of a classification is applicable and outlined perceived standards of such review. The discussion in Developments in the Law-Equal Protection, 82 HaRv. L. REv. 1065 (1969), represents the most complete conceptualization of "active" review. For other recent commentary, see Michelman, Forward: On Protecting the Poor Through the Fourteenth Amendment, 83 Harv. L. REv. 7 (1969); Sager, Tight Little Islands: Exclusionary Zoning, Equal Protection, and the Indigent, 21 STAN. L. Rev. 767, 774-80 (1969). See generally Black, Forward: "State Action," Equal Protection and California's Proposition 14, 81 HARv. L. REV. 69 (1967); Cox, Forward: Constitutional Adjudication and the Promotion of Human Rights, 80 HARv. L. Rev. 91 (1966); Horowitz, Unseparate But Unequal-The Emerging Fourteenth Amendment Issue in Public School Education, 13 U.C.L.A.L. Rev. 1147 (1966); Karst \& Horowitz, Reitman v. Mulkey: A Telophase of Substantive Equal Protection, 1967 Sup. Cr. REv. 39; McKay, Political Thickets and Crazy Quilts: Reapportionment and Equal Protection, 61 MiCH. L. REv. 645 (1963).

17. Developments 1128 . It is also clear that the group of rights protected by the Constitution is limited but not fully defined. See Griswold v. Connecticut, 381 U.S. 479 (1965).

18. E.g.. Reynolds v. Sims, 377 U.S. 533 (1964) (voting); Grifin v. Illinois, 351 U.S. 12 (1956) (criminal appeals); Skinner v. Oklahoma ex rel. Williamson, 316 U.S. 535 (1942) (procreation).

19. 397 U.S. 471 (1970). 
statutory differentiation have been suggested as being "suspect,"20 racial classifications represent the archetype and only uniformly recognized suspect category. ${ }^{21}$ A survey of relevant decisions and commentary reveals two general bases for that characterization. First, there is a presumptive probability that no rational relation exists between the use of a racial classification and the furthering of a legitimate state interest, because classifying on the basis of race is possibly related to very few permissive state interests, ${ }^{22}$ and because racial classifications affect minority groups having a minimal ability to participate effectively in the political process. ${ }^{23}$ Second, racial classifications are not favored because the past use of racial classifications to designate inferiority has attached a stigma of opprobrium to any classification on that basis. Even if a particular racial classification is rational and not simply based on prejudice, it will generally be perceived as a means of identifying and discriminating againșt "second class" members of society. ${ }^{24}$

20. E.g., Harper v. Virginia Bd. of Elections, 383 U.S. 663 (1966); Griffin v. Illinois, 35 ! U.S. 12 (1956) (wealth); Korematsu v. United States, 323 U.S. 214 (1944) (lineage). The implication in Levy v. Louisiana, 391 U.S. 68 (1968), and Glona v. American Guar. \& Liab. Ins. Co., 391 U.S. 73 (1968), that illegitimacy is a suspect basis of classification was disregarded in and has apparently been negated by Labine v. Vincent, 39 U.S.L.W. 4344 (U.S. Mar. 29, 1971).

21. See Shapiro v. Thompson, 394 U.S. 618, 659 (1969) (Harlan, J., dissenting). See also Developments 1088 n.57.

22. Hirabayashi v. United States, 320 U.S. 81, 100 (1943) (dicta). The fact that race is a congenital and unalterable trait reinforces the notion that it is presumptively not constitutionally relevant. See Developments 1127, 1174.

23. Mr. Justice Stone's famous footnote constitutes the touchstone for special consideration of minorities. "[P]rejudice against discrete and insular minorities may be a special condition, which tends seriously to curtail the operation of those political processes ordinarily to be relied upon to protect minorities and which may call for a correspondingly more searching judicial inquiry." United States v. Carolene Prods. Co., 304 U.S. 144, 153 n.4 (1938). See Hobson v. Hansen, 269 F. Supp. 401, $507-08$ n.198 (D.D.C. 1967), aff d sub nom. Smuck v. Hobson, 408 F.2d 175 (D.C. Cir. 1969).

24. Developments 1127. See Black, The Lawfulness of the Segregation Decisions, 69 YALE L.J. $421,424(1960)$. The historical background of the fourteenth amendment has also been cited as explaining special treatment for racial classifications. Loving v. Virginia, 388 U.S. 1, 10 (1967); Developments 1125.

It should be noted that a classification affecting the exercise of a fundamental right is "suspect" because of its effect on the exercise of that right. Such a form of suspect classification simply represents a different conceptualization of the fundamental rights portion of the compelling state interest test. See Shapiro v. Thompson, 394 U.S. $618,660 \mathrm{n} .9$ (1969). Also, wealth has been considered a "suspect" basis for classification, not because a state's charging payment for goods and services is irrational, but because the critical nature of certain interests and services prompts special concern when the poor are discriminated against in respect to them. See, e.g., Williams v. lllinois, 399 U.S. 235 (1970); McDonald v. Board of Election Comm'rs, 
When active judicial review is triggered by a state's use of suspect classifying criteria or the impact of the criteria on the exercise of a constitutional right, the evaluation of whether the classification is justified as furthering a compelling state interest first involves a consideration of the general importance of the interest to be served..$^{25}$ In some decisions involving active review, establishing the requisite governmental interest has involved both a consideration of the magnitude of the state interest and a determination of whether such interest outweighed the disadvantage suffered by the class adversely affected by the statute..$^{25}$ However, in Shapiro $v$. Thompson, where the compelling interest test was first openly articulated by the Supreme Court, the Court simply evaluated the importance of the state interest without regard to the disadvantage suffered by the affected class. ${ }^{27}$ In practical terms the use of either approach probably represents only a difference between explicit and implicit balancing. ${ }^{2 s} \mathrm{~A}$ court that perceives or does not perceive a state interest of compelling import using either method would be very unlikely to view things differently following the other approach. ${ }^{29}$ Furthermore, even if the interest served is considered compelling, the use of the classification must itself be more than reasonably appropriate. A substantial degree of connection must exist between using the particular classification and realizing the stated objective. ${ }^{30}$ Finally, a classification is not compellingly justified if alternative means of accomplishing the desired result exist that do not involve use of suspect criteria or similarly affect a fundamental right. ${ }^{31}$

Although recognizing that the alien is protected by the fourteenth

394 U.S. 802, 807 (1969) (dicta); Harper v. Virginia Bd. of Elections, 383 U.S. 663, 666-68 (1966); Douglas v. California, 372 U.S. 353, 357 (1963).

Lineage and illegitimacy have been viewed as suspect for the same reasons as race. See Developments 1124-27.

25. Shapiro v. Thompson, 394 U.S. 618,637 (1969).

26. E.g., Reynolds v. Sims, 377 U.S. 533, 579-80 (1964); Douglas v. California, 372 U.S. 353, 356-57 (1963). Compare Korematsu v. United States, 323 U.S. 214 (1944), with Buchanan v. Warley, 245 U.S. 60 (1917). See also Developments 1103-04, 1122-23.

27. 394 U.S. 618,638 (1969).

28. It might be argued that when a fundamental right is affected by a classification, no explicit balancing is appropriate since a demand for a public interest of importance represents implicit weighing of both public and private interests.

29. No opinion has been found which makes reference to a conscious decision to use one approach as opposed to the other in determining whether a compelling state interest is furthered.

30. See Van Alstyne, Student Academic Freedom and the Rule-Making Powers of Public Universities: Some Constitutional Considerations, 2 LAW IN TRANs. Q. 1 (1965).

31. Id. 
amendment, ${ }^{32}$ the Supreme Court in the early twentieth century, utilizing the lesser standard of review, repeatedly validated restrictions on alien status. The alien's rights to hold land, ${ }^{33}$ share in the resources of the state, ${ }^{34}$ find employment in public work, ${ }^{35}$ and work in several private occupations ${ }^{35}$ were limited and in many instances abrogated. States were considered to have a proprietory interest in conserving public employment and resources for their rightful owners, the citizens of the state, and exclusion of non-citizens from those benefits was viewed as rationally related to a permissible state interest. ${ }^{37}$ The state's interest in regulating harmful and dangerous private occupations was viewed as reasonably furthered by excluding one class, aliens, from employment in those occupations. ${ }^{38}$ The disability of aliens to hold land freely was grounded on both the interest of the state as proprietor of the citizens' resources and the state's police power to insure proper use of state land. ${ }^{39}$ Even so, in 1915 the Supreme Court did restrict a flagrant application of an underinclusive classification in holding that the police power only authorized exclusion of aliens from occupations in which the state held a "special interest." 40 Excluding aliens from "common occupations" was held not to be related rationally to promoting the health, safety, morals, and welfare of individuals within the state."11

32. Protection of the fourteenth amendment was extended to aliens in Yick Wo v. Hopkins, 118 U.S. 356 (1886).

33. Cockrill v. California, 268 U.S. 258 (1925); Webb v. O'Bricn, 263 U.S. 313 (1923); Frich v. Webb, 263 U.S. 326 (1923); Porterfield v. Webb, 263 U.S. 225 (1923); Terrace v. Thompson, 263 U.S. 197 (1923).

34. Patsone v. Pennsylvania, 232 U.S. 138 (1914); McCready v. Virginia, 94 U.S. 391 (1877).

35. Heim v. McCall, 239 U.S. 175 (1915); Atkin v. Kansas, 191 U.S. 207 (1903). For criticism of those decisions, see Note, Constitutionality of Restrictions on Aliens' Right to Work, 57 Colum. L. Rev. 1012 (1957); Note, The Right to Work for the State, 16 Colum. L. Rev. 99 (1916); Note, National Power 10 Control State Discrimination Against Goods and Persons: A Study in Federalism, 12 StaN. L. Rev. 355, 367 (1960).

36. Ohio ex rel. Clarke v. Dechebach, 274 U.S. 392 (1927); Murphy v. California, 225 U.S. 623 (1912).

37. See Heim v. McCall, 239 U.S. 175 (1915); Patsone v. Pennsylvania, 232 U.S. 138 (1914); Atkin v. Kansas, 191 U.S. 207 (1903); McCready v. Virginia, 94 U.S. 391 (1877).

38. Ohio ex rel. Clarke v. Dechebach, 274 U.S. 392 (1927); Murphy v. California, 225 U.S. 623 (1912).

39. Cockrill v. California, 268 U.S. 258 (1925); Frich v. Webb, 263 U.S. 326 (1923); Wcbb v. O'Brien, 263 U.S. 313 (1923); Porterfield v. Webb, 263 U.S. 225 (1923); Terrace v. Thompson, 263 U.S. 197 (1923).

40. Truax v. Raich, 239 U.S. 33 (1915).

41. 239 U.S. at $4 \mathrm{I}-43$. 
In the 1940's the Supreme Court began to consider more closely restrictive classifications related to alienage. In Korematsu v. United States $^{42}$ the Court, although upholding restrictions on persons of Japanese ancestry during World War II, stated that such restrictions are "immediately suspect," must be subjected to "rigid scrutiny," and were only justified by "public necessity." 33 Also, even though in Oyama v. California $a^{\text {t4 }}$ the Court declined to invalidate California's alien land $1 \mathrm{lw}^{45}$ it did void a statutory presumption that land purchased by an ineligible alien and recorded in his son's name was not a gift to his citizen son. The court equated the presumption with discrimination against the citizen son on the basis of his racial discent and stated that only a compelling justification could sustain such discrimination. Furthermore, in Takahashi v. Fish \& Game Commission ${ }^{46}$ it was held that any proprietary interest of the state as trustee-owner of fish swimming three miles off-shore was insufficient to justify exclusion of aliens from commercial fishing. Significantly, the Supreme Court eschewed reliance on the fact that the statute was blatantly designed to only prohibit one racial group, alien Japanese, from fishing. The fourteenth amendment was said to

protect "all persons" against state legislation bearing unequally upon them either because of alienage or color. . . . [and]

... the power of a state to apply its laws exclusively to its alien inhabitants as a class is confined within narrow limits. ${ }^{47}$

As a result of Korematsu, Oyama, and Takahashi, questions have arisen as to the validity of the earlier cases upholding restrictions on aliens, and alienage has often been referred to as a "suspect" basis of classification. ${ }^{48}$ However, the more intensive review by the Court in those cases could be interpreted as based upon an equivalence in fact between restrictive classification of aliens and discrimination based on race or ancestral lineage. For in each instance, the statutes were

42. 323 U.S. 214 (1944). See also Hirabayashi v. United States, 320 U.S. 81 (1942) (curfew on all persons of Japanese ancestry upheld).

43. 323 U.S. at 216.

44. 332 U.S. 633 (1948).

45. "The Alien Land Law forbids aliens ineligible for American citizenship to acquire, own, occupy, lease, or transfer agricultural land." 332 U.S. at 636.

46. 334 U.S. 410 (1948).

47. 334 U.S. at 420 (emphasis added).

48. E.g., Developments I125; 38 GEO. WASH. L. Rev., supra note II, at 1102; 1970 UTAH L. REv., supra note 9, at 136.

The Supreme Court itself specifically cited Takahashi to illustrate an "inherently suspect" classification. Kramer v. Union Free School Dist., 395 U.S. 621, 628 n.9 (1969). 
meant to and did affect only one group of aliens, the Japanese. Furthermore, although the Court referred generally to alienage in Takahashi, it also cited the cases relying on the proprietary power of the state over state resources and did not explicitly overrule them. ${ }^{49}$ Also, there is language in the opinion that may be interpreted to mean that, irrespective of the validity of the proprietary theory itself, the state in that instance simply did not have sufficient property interest in the offshore fish to justify application of its proprietary power. ${ }^{50}$ Moreover, there is still other language indicating that the decision simply involved regulation of a private occupation and the invalidity of excluding one group from commercial fishing without a special public interest in so doing. 51

In attempting to delineate the degree of alien protection under the fourteenth amendment, different lower courts have reached somewhat varied results. In Hosier v. Evans ${ }^{52}$ a federal district court invalidated restrictions on alien children's rights to attend public school. The court did not allude to alienage as an inherently suspect basis of classification but grounded its demand for more than a rational relationship to advancing the public welfare solely on the fact that the "right" to free public education was affected. In Richardson $v$. Graham $^{53}$ an Arizona federal district court invalidated a 15-year residency requirement for aliens as a condition of eligibility for general welfare assistance, assistance for the blind, and old age assistance. The court made brief mention of Takahashi but basically relied upon Shapiro $v$. Thompson, ${ }^{54}$ which held that a citizen's right to

49. The Court cited McCready v. Virginia, 94 U.S. 391 (1877), and Patsone v. Pennsylvania, 232 U.S. 138 (1914), without commenting on their validity. 334 U.S. at 420-21.

50. " 'To put the claim of the State upon title is to lean on a slender reed' . . . . We think that same statement is cqually applicable here." 334 U.S. at 421.

51. "We are unable to find that the 'special public interest' on which California relies provides support for this state ban on Takahashi's commercial fishing." Id. at 420 .

The difficulty in interpreting Takahashi is highlighted by the fact that even commentators who agree that case did not make alienage "suspect," disagree in their overall interpretations. One student commentator believes that the decision invalidated the line of alien cases rclying on the proprietary rationale while the cases relying on the police power of the state to regulate working conditions were not overruled. II HARv. INT'L L.J. 228, 236 (1970). However, a federal district court judge has maintained that Takahashi was a case that only involved regulation of private enterprise and was not concerned with the proprietary interest of the state in its resources. Leger v. Sailer, 321 F. Supp. 250 (E.D. Pa.) (dissenting opinion), prob. juris. noted, 400 U.S. 956 (1970).

52. 314 F. Supp. 316 (D.V.I. 1970).

53. 313 F. Supp. 34 (D. Ariz. 1970).

54. 394 U.S. 618 (1969). 
travel was so affected by a residency requirement for state aid that a compelling state interest must be posited. The Richardson court implicitly extended the right to travel to aliens and upon finding a lack of a compelling state interest, voided the residency requirements. Even though Shapiro and its supporting cases indicate that the right to travel extends only to citizens, ${ }^{55}$ general language in other cases indicates that it should extend to aliens. ${ }^{56}$ More importantly, denial of aid altogether to aliens would avoid interference with any travel right since there would be no discrimination in terms of the exercise or nonexercise of the Shapiro right to travel; an alien would not feel constrained to remain in a state so that he eventually could fulfill the residency requirement and receive aid. Thus, the Richardson decision in no way resolves the status of alienage classifications themselves under the equal protection clause.

In Purdy \& Fitzpatrick v. State ${ }^{57}$ the California Supreme Court unanimously held a statute prohibiting employment of aliens on public works projects to be invalid. The court interpreted Takahashi to mean that alienage was a suspect basis of classification and that the proprietary theory no longer had vitality. Emphasis was placed on the irrationality of preserving state resources solely for their supposed owners, the citizens of the state, when aliens must pay taxes and serve in the armed forces. This irrationality was seen to be increased by the fact that aliens may live and work within a state and contribute to its economic growth for many years. It was also stressed that the proprietary rationale had partially rested on the doctrine that a state has unqualified power in extending privileges ${ }^{58}$ and that such a rightprivilege distinction no longer has legitimacy ${ }^{59}$ The court further held

55. See United States v. Guest, 383 U.S. 745, 757-58 (1966); Edwards v. California, 314 U.S. 160, $181^{\circ}$ (Douglas, J., concurring), $183-85$ (Jackson, J., concurring) (1941); Twining v. New Jersey, 211 U.S. 78, 97 (1908); Ward v. Maryland, 79 U.S. (12 Wall.) 418, 430 (1870); Paul v. Virginia, 75 U.S. (8 Wall.) 168, 180 (1868); Corfield v. Coryell, 6 F. Cas. 546, 552 (No. 3230) (C.C.E.D. Pa. 1825). See also Zemel v. Rusk, 381 U.S. 1, 14 (1965); Aptheker v. Secretary of State, 378 U.S. 500, 505-06 (1964); Kent v. Dulles, 357 U.S. 116, 125 (1958) (freedom to travel outside United States).

56. See Takahashi v. Fish and Game Comm'n, 334 U.S. 410,416 (1948); Truax v. Raich, 239 U.S. 33,42 (1915).

57. 71 Cal. 2d 566, 456 P.2d 645, 79 Cal. Rptr. 77 (1969) (en banc).

58. See People v. Crane, 214 N.Y. 159, 164, 108 N.E. 425, 430, aff d, 239 U.S. 195, 199 (1915); McCready v. Virginia, 94 U.S. 391 (1876).

59. Shapiro v. Thompson, 394 U.S. 618, 627 n.6 (1969); Sherbert v. Verner, 374 U.S. 398, 404 (1963). See Van Alstyne, The Demise of the Right-Privilege Distinction in Constitutional Law, 81 HaRv. L. Rev. 1439 (1968). 
that the police power of the state to promote acceptable wages and working conditions in the construction industry did not authorize exclusion of aliens from the industry since the classification bore no rational relationship to any valid implementation of that power. In light of the court's rejection of the proprietary and police power rationale, the classification in Purdy would necessarily seem to fail even under-permissive standards because no other legitimate state interests related to the exclusion of aliens from public works were offered. However, notwithstanding its earlier analysis, the court, rather cryptically, also conceded that favoring United States citizens over citizens of other countries was a legitimate state interest without providing an explanation of how such discrimination was legitimate. Thus, the characterization of alienage as suspect appears to have been crucial; the statute was invalidated only because it favored United States citizens in the absence of a compelling state interest. ${ }^{60}$

A divided Pennsylvania federal district court in Leger v. Sailer ${ }^{61}$ relied on Purdy in striking down a statute which denied general welfare assistance to aliens. The same arguments used in Purdy were marshalled against the validity of the proprietary rationale, but the same concession was made in recognizing that "[t]here may be an area in which the state may permissiably preserve natural resources for its own citizens by discriminating against aliens . . ." 62 The court further recognized a valid state interest in conserving the state treasury but viewed that interest outweighed in the present case by the severity of the deprivation upon the excluded group. ${ }^{63}$ Such an analysis creates the same logical difficulties noted in reference to Purdy. States do have a legitimate interest in conserving state funds, but even under permissive equal protection standards the selection of a group to exclude from aid in order to economize must be rational. In other words, if a state has only enough funds to aid a certain

60. Besides invalidating the statute on equal protection grounds, the court also found that it encroached upon the congressional scheme for immigration and naturalization. $71 \mathrm{Cal} .2 \mathrm{~d}$ at 572-78, 456 P.2d at 649-53, 79 Cal. Rptr. at 81-85. See 38 GEo. WASH. L. Rev., supra note 11, at 1110-11; 11 HARV. INT'L L.J. 228, 229-34 (1970). See generally 12 STAN. L. REV., supra note 35.

61. 321 F. Supp. 250 (E.D. Pa. 1970).

62. Id. at 255.

63. There was evidence that non-citizen applicants for general assistance are less than 100 per year. Id. at 254. The dissenting judge felt that Takahashi simply involved regulation of commercial fishing, denied that it had made alienage "suspect" or that it had discrediled the proptietary rationale, and would have upheld denial of assistance on that basis. Id. at 256.60 (dissenting opinion). 
percentage of needy individuals, it cannot arbitrarily exclude one class of individuals to make its aid program fiscally feasible. If the proprietary theory is truly invalid, then, given the absence of any state interest other than simply the desire to favor citizens over aliens, exclusion of aliens from state aid should fail without the necessity of balancing the interest involved. Moreover, the implication of the singular use of a balancing approach is that a great increase in the number of alien applicants for aid might cost the state so much money as to predicate a compelling interest in economy and thus validate the denial of aid to aliens.

In Gonzales $v$. Shea ${ }^{64}$ the lack of any invidious purpose or motive in the origin of the citizen requirement was initially noted. The court recognized that the old age pension law involved basic economic needs but relied on Dandridge $v$. Williams ${ }^{65}$ in holding that the interests affected did not merit application of the compelling interest test. However, the court did conclude that in Takahashi, because of the presence of a classification based on alienage, the Supreme Court had applied a balancing test ${ }^{66}$ which demanded a stronger state interest than that required in standard equal protection review. Yet, alienage was not necessarily viewed as "suspect." Even so, the court concluded that in view of Takahashi and because a balancing approach appeared more reasonable and less mechanical than applying a proprietary criterion, there should be at least a guarded or cautious weighing of opposing interests. In applying that balancing test, the court reasoned that since the plaintiffs were receiving other forms of public assistance, the infringement on personal interests was less drastic and severe in the instant situation than had existed in Dandridge. The pension program was seen as a special and deeply rooted one, funded in the nature of a trust, adopted and maintained after bitter struggle. Moreover, because the citizenship requirement probably could not be severed, a holding of invalidity would destroy the program and adversely affect the interests of the recipients for whose benefit the fund was created. Because of these factors the court considered that the Colorado amendment was unique and distinguished both Leger and Richardson as involving discrimination of greater magnitude when weighed against the state interest. Even though a need for a

64. 318 F. Supp. 572 (D. Colo. 1970).

65. 397 U.S. 471 (1970). See notes $19 \& 20$ supra and accompanying text.

66. The court felt that a balancing test was "similar" to the compelling state interest test enunciated and articulated in Shapiro. 318 F. Supp. at 578. 
compelling interest had been disavowed, the court found that the reasons supporting the classification were compelling and sustained its validity.

Several preliminary observations may be made concerning Gonzales. Although proof of an impermissible motive or purpose may be relevant to prove invidious discrimination, lack of such a motive or purpose certainly does not cure a functionally invidious scheme of discrimination. ${ }^{67}$ Furthermore, in evaluating the personal interests affected, the court should have considered that some aliens might be solely dependent on old age assistance for subsistence. Yet, a more basic difficulty exists with the analysis in Gonzales. While consideration of the importance of a state's objective is relevant when compelling justification for a classification is deemed necessary, equal protection analysis more basically centers on evaluating the degree of rational relationship between the use of a particular classification and furthering a legitimate state interest. ${ }^{68}$ At no time did the Gonzales court consider how the exclusion of the class of aliens from eligibility for pension benefits, as opposed to excluding any other group, furthered any permissive state interest. Proper equal protection analysis demands that a choice of a classification involve more than an ability to make a program politically acceptable. ${ }^{69}$ The Gonzales reasoning would justify any statutory classificetion if used in a program of overall importance and if continued existence of the program depended on retention of the classification. For example, if a state only provided welfare benefits to needy Democrats because Democrats were in the majority, had done so for numerous years with wide acceptance, and could not secure the passage of a general welfare statute for political reasons, the state would have the same "compelling interest" in upholding the program as existed in Gonzales.

Despite the weaknesses in the Gonzales decision, the recognition that alienage is not a "suspect" classification, the use of which demands full compelling justification, must be applauded. Notwithstanding the apparent conclusiveness of the holdings in Purdy

67. See Baker v. Carr, 369 U.S. 186, 266 (1962); Valtierra v. Housing Auth., 313 F. Supp. 1 (N.D. Cal. 1970), rev'd on other grounds sub nom. James N. Valtierra, 39 U.S.L.W. 4488 (U.S. April 27, 1971). For an excellent discussion of when proof of bad motive is relevant and implicit recognition that lack of proof of bad motive is irrelevant, see Ely, Legislative and Administrative Motivation in Constitutional Law, 79 YALE L.J. 1205, 1212-22, 1269-75 (1970).

68. Tussman \& ten Broek, supra note 12, at 344; Developments 1076.

69. Tussman \& ten Broek, supra note 12, at 349-50. 
and Leger, there is neither legitimate precedent nor any other valid reason for so characterizing alienage classifications. First of all, the alien cases referring to classifications as meriting strict scrutiny all involved restrictions on one particular group of aliens. ${ }^{70} \ln$ Takahashi, when the Supreme Court indicated that the state's power to apply its laws exclusively to its alien inhabitants was confined within narrow limits, the Court was merely noting that application of traditional . fourteenth amendment standards and the supremacy of federal laws governing alien status limited the state's power to regulate aliens. ${ }^{71}$ Of greater importance is the fact that classifying on the basis of alienage is simply not "suspect" in the manner or to the degree as classifying on the basis of race. No badge of inferiority is associated with alienage classifications. Also, alienage is not an immutable, inherent quality which, when used as a classifying factor, is possibly related to very few permissible state objectives. Alienage is a governmentally created status that is clearly relevant when used to classify individuals in order to further some state interests. In some contexts special treatment of those who do not meet the requirements of citizenship is manifestly justified; for example, the validity of federal differentiation between citizens and aliens in regulating entry into the country is axiomatic. ${ }^{22}$ Even so, at least some elements of the panoply of federal regulations over immigration and alien status within the United States facilitate only the convenience and administrative process of the federal government. ${ }^{73}$ However, invalidation of such regulations because classification of aliens is "suspect" and need serve a compelling interest would seem rather strange. ${ }^{74}$ The classification of aliens in that context appears presumptively rational, and, unless no reasonable relation to a legitimate state interest can be sliown, voiding such a classification is unwarranted. Likewise, one may disagree with the particular requirements of citizenship, but the very essence of citizenship is membership in the body politic.;5 a prerequisite of citizenship to vote or hold public office would seem eminently

70. See, e.g., Korematsu v. United States, 323 U.S. 214 (1944); Hirabayashi v. United States, 320 U.S. 81 (1943).

71. 334 U.S. at $419-20$.

72. See 8 U.S.C. §§ 1101-1503 (1964).

73. E.g., id. $\$ \S 1301-06$ (1964) (providing for registration of aliens).

74. It is assumed that the federal government is subject to an equal protection requirement by means of the fifth amendment. Bolling v. Sharpe, 347 U.S. 497 (1954).

75. See Luria v. United States, 231 U.S. 9, 22 (1913); Minor v. Happersett, 88 U.S. (21 Wall.) $162,165.66$ (1874). 
reasonable. Yet, if alienage is "suspect," a requirement of citizenship for a state or local office must further a compelling state interest. Given the rigor of that test the requirement might conceivably fail. Admittedly, some courts would sustain such restrictions because of their obvious rationality and in so doing recognize the requisite state interest. However, the point to be made is that even the possibility of invalidation on such a basis illustrates the weaknesses of straightforward application of a compelling interest test to the classification of aliens.

Proper application of simply the reasonable relation standard of review should invalidate the type of restrictions reviewed in Purdy, Leger, and Gonzales. All three courts concluded that the proprietary rationale could not by itself validate the discrimination in each case. Although the Supreme Court in Takahaski did not make alienage "suspect," it did indicate that the proprietary rationale would not support exclusion of aliens from a private occupation or enjoyment of state resources. ${ }^{76}$ The "demise of the right-privilege distinction,"77 the equality of obligations, and the probability of equality of contribution to the state by the alien do establish that the alien is no less "deserving" of receiving aid or holding public employment than the citizen. This reasoning implies that the state interest of favoring citizens over aliens voiced in Purdy is simply a restatement of the decision to discriminate and is not legitimate. Similarly, the state interests cited in Leger and Gonzales are valid, but the choice of the classification excluding aliens is not rationally related to furthering them.

Even though alienage classifications do not justifiably trigger a demand for compelling justification and even though the restrictions in the foregoing cases should have failed under any equal protection standard, difficulties remain. The widespread references to and treatment of alienage classifications as "suspect" are not without some meaning or merit. Aliens are not merely politically disadvantaged along with many other groups in society; they are without the power of the ballot and have no political power. Furthermore, a past history of open discrimination against them does

76. "To whatever extent the fish . . . may be 'capable of ownership' by California, we think that 'ownership' is inadequate to justify California in excluding any or all aliens who are lawful residents of the State from making a living by fishing in the ocean off its shores while permitting all others to do so." 334 U.S. at 421 (emphasis added).

77. Van Alstyne, note 59 supra. 
exist. ${ }^{78}$ Thus, even though the use of alienage classifications is clearly related to furthering some legitimate state interests and does not represent a badge of inherent. inferiority, such classifications do share with racial classifications a greater likelihood of irrationality than other bases. In most instances, when there is no reason for any suspected irrationality in classification, the traditional standard of review is tolerable and desirable even though it is extremely permissive and allows states great latitude in classification. With neutral bases on which to classify, no proclivity toward purely invidious discrimination exists, and the political process effectively checks such discrimination. ${ }^{79}$ However, the likelihood of invidious discrimination against aliens and their lack of any political power indicates that similar deference to restrictions on aliens is unjustified and unwarranted.

While neither the permissive nor the compelling interest standard of review as presently conceptualized can properly be applied to alienage classifications, an intermediate standard of review should be formulated which reflects the limited suspect nature of those classifications. A preliminary determination should be made as to whether aliens constitute the basic group ideally affected by a statute. A statute restricting aliens which is neither under-inclusive or overinclusive with respect to furthering a valid state interest should be upheld. Such a determination must allow for the practical difficulties and exigencies in attempting to draft any statute. However, to satisfy the test a state must demonstrate not only the rationality of affecting aliens but also must posit a direct connection between affecting only aliens and realizing a legitimate purpose. The availability of more exact means of classification certainly would be relevant in determining whether a statute is substantially precise. Such substantial precision in classification would sufficiently indicate the rationality of the classification in that particular context. However, when the classification does not identify the class ideally affected, a fully compelling state interest should be evidenced. Because of the suspect-albeit limited - nature of classifying on the basis of alienage, the state should be required to show a great need to classify on that basis in order to insure against purely invidious discrimination when aliens do not comprise the class ideally affected.

78. See Oyama v. California, 332 U.S. 633, 651 (1948) (concurring opinion); Fujii v. State, 38 Cal. 2d 718, 242 P.2d 617 (1952).

79. See Lee Optical Co. v. Williamson, 348 U.S. 483, 488 (1955). 
The suggested scope of intermediate review should accurately reflect the nature of special concern for classifications based on alienage. In other instances of active review it is always logical to require the furtherance of a state interest of magnitude. For example, when a fundamental right is affected, a compelling state interest is needed to outweigh the effect on personal rights even if a classification is precise. ${ }^{80}$ Furthermore, because of the stigma attached to racial classifications, a demand that the state always posit a compelling interest in classifying on that basis is appropriate. However, the suspected irrationality of classifying on the basis of alienage can be allayed in some instances without demanding a compelling state interest; then, limited active review is appropriate.

Use of an intermediate standard of review would not be without considerable difficulty. The determination of whether a classification is precisely related to furthering a particular state interest is certainly not automatic nor necessarily easily resolvable. However, a determination of that nature is presently a part of full active review, and no additional form of judicial inquiry is required. ${ }^{81}$ Some cases, such as the determination of whether citizenship is a legitimate prerequisite to vote, are capable of easy adjudication. However, other cases will remain very difficult. For example, a requirement of United States citizenship for admission to a state bar ${ }^{82}$ does not represent a precisely drawn classification. The moral qualities and adherence to the principles of our legal system do not necessarily presuppose allegiance to and membership in the body politic of the United States. However, the requirement is not without rationality. Other factors being equal, a United States citizen is more likely than an alien to recognize and adhere to the precepts of our legal system. Also, the practical cost of assessing the character of an alien in many cases would be prohibitive. Yet, because a more precisely drawn requirement, such as placing the burden on the applicant of financing and satisfying an examining committee of one's requisite character, would enable at least some aliens to establish legitimate qualification, the citizenship requirement probably should fail.

Finally, this intermediate pattern of review provides a means of

80. E.g., Shapiro v. Thompson, 394 U.S. 618 (1969).

81. Evaluating the precision of a classification involves the same type of inquiry as does the demand for substantial connection between a classification and the furthering of a state interest made under present standards of active review. See note 30 supra and accompanying text.

82. E.g., UTAH CODE ANN. § 78-51-10 (1953). 
expanding judicial notions of bases of classification that merit something more than traditional review. Presently, equal protection review is either very permissive or extremely demanding. Thus, although certain bases of classification- $\operatorname{sex}^{83}$ and age, ${ }^{84}$ especially for youths under voting age-have been suggested as "suspect" because of a suspicioned irrationality in their use, active review is now so stringent that suspect characterization portends invalidating all classifications utilizing those criteria. Resistance to such a characterization can presently be justified because of the value and rationality of using those classifying factors in certain contexts. As demonstrated in reference to alienage, a degree of intermediate review is possible that would provide considerable protection against the invidious use of such factors in statutory classification but would also allow for their use when demonstrably appropriate.

83. Cf. Commonwealth v. Daniels, 430 Pa. 642, 253 A.2d 400 (1968), noted in 82 HARv. L. Rev. 821 (1969); Developments 1174. For implicit treatment of sex as a "suspect" basis of classification, see Mollere v. Southeastern Louisiana College, 304 F. Supp. 826 (E.D. La. 1969).

84. See generally In re Gault, 387 U.S. I (1967); Karst, Invidious Discrimination: Justice Douglas and the Return of the "Natural Law Due Process Formula", 16 U.C.L.A.L. Rev. 716, 741 (1969); Van Alstyne, The Student as University Resident, 45 DENVER L.J. 582 (1968). 
. 